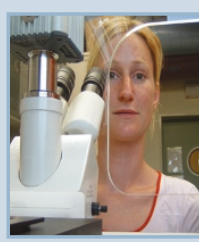

\author{
p720 Helping hand: \\ A new fellowship \\ offers female graduate \\ students much- \\ needed funds.
}

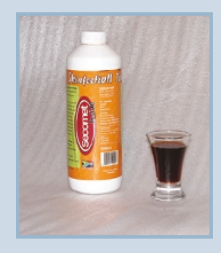

\author{
p723 Murky \\ medicine: South \\ African scientists \\ are promoting an \\ untested AIDS drug.
}

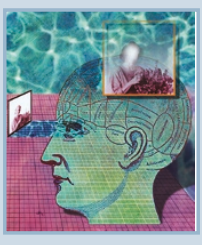

p747 Amyloid

debates: Why is one

protein in Alzheimer

disease the center

of controversy?

\title{
Informed consent issues hobble cancer genome scheme
}

The federal government's ambitious cancer genome project is facing daunting ethical and practical hurdles, barely months after its launch.

The Cancer Genome Atlas aims to catalog the genetic mutations associated with cancer based on tumor samples from tissue banks. The sequence information would be available on an internet database, and is hoped to help develop therapies for cancer.

A $\$ 100$ million pilot phase of the project began in March and grants are expected to be doled out in late July. The project is expected to cost more than $\$ 1$ billion over the next decade.

Before researchers begin their work, however, project administrators at the US National Institutes of Health (NIH) must first find appropriate tumor samples and set strict guidelines to protect donors' identities. At a series of meetings since July 2005, organizers and an advisory committee composed of external experts have furiously debated matters of informed consent, access to the database and the potential privacy risks associated with an internet database.

Researchers plan to use more than 1,000 tumors from US tissue banks, but the samples will need to have signed consent forms from donors allowing their genetic information to be made publicly available. The tumors must also meet a long list of criteria: they must be of a certain quality and homogeneity, at a certain stage of development, preserved correctly and from patients not treated for cancer.

But there simply may not be enough such samples, some experts predict. "It doesn't look wildly promising," says Sean Eddy, a geneticist at Washington University in St. Louis and a member of the advisory committee.

The organizers may instead have to track down donors, if they are still alive, and get broader consent-a costly, time-consuming and risky proposition.

Asking donors for permission also raises questions about the consent process, and how best to educate donors about the implications of posting their DNA on the internet.

"A big part is educating the patient to make sure they understand the risks," says Amy McGuire, a bioethicist at the Baylor College of
Medicine in Houston. "It's very difficult when you're dealing with complex issues such as DNA sequencing and the risks and benefits of public data."

There is a danger, for example, that new technology for searching genetic databases could allow employers, police departments, health insurance companies and even other scientists to abuse the information and to mine the data for other reasons, such as for forensics, stigmatizing racial studies or tracing biological parents.

"We're clearly setting some precedents here and we have to be careful," says Mark Guyer, a project manager at the US National Human Genome Research Institute.

In the early 1990s, members of the Havasupai Tribe, a Native American group

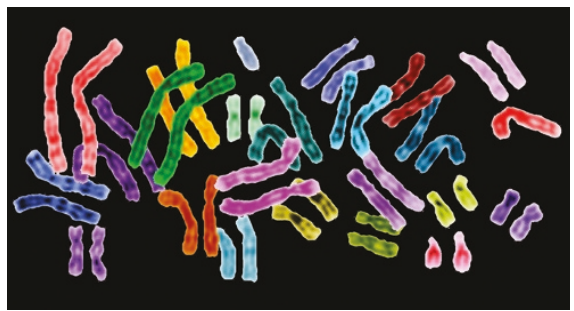

in Arizona, donated blood samples to researchers at Arizona State University for a study on the high prevalence of diabetes in the tribe. But in 2004, the Havasupai sued the Arizona researchers, accusing them of sharing the information with other scientists, and for using the data to study inbreeding, schizophrenia and migration patterns (Nature 430, 500-502; 2004).

It may be possible to prevent such abuse of the information by creating tiered access to the database, with only parts of it fully available online, or by granting access to a select few scientists.

But some experts say that won't be necessary, noting that samples in the database will not be linked to personal details such as name and social security number.

"The goal of this project is to bring better therapies to people as quickly as possible," says Brian Druker, a leukemia specialist at Oregon Health \& Science University and a member of the advisory committee. "If you have to sacrifice the very tiny risk of breach of patient confidentiality, I'm willing to take that risk.'

Emily Waltz, New York

\section{NIH scandal underscores lack of sample oversight}

Pay a visit to the website of The Cancer Genome Atlas, and you'll find this reassuring statement about the samples scientists hope to obtain for the project: "Tissue samples will be carefully catalogued, processed, checked for quality and stored, complete with important medical information about the patient."

The information will have limits, the website hastens to add, and "samples will be coded to remove any descriptors that might connect a sample with the patient's private information."

But will those assurances be enough to win donors' confidence? In June, Congressional investigators disclosed a National Institutes of Health (NIH) finding that Trey Sunderland, an NIH researcher, had committed "serious misconduct" when he shipped 3,200 samples of cerebrospinal fluid to the pharmaceutical company Pfizer. Sunderland did so without authorization and without reporting the more than $\$ 600,000$ in consulting fees he received from the company- $\$ 285,000$ of it for work related to the samples.

The Congressional report said that the case raises "serious questions" about inadequate oversight and control of human tissue samples at the NIH.

"I can't imagine it's going to strengthen people's faith in the NIH or in science," says Thomas Murray, president of the Hastings Center, a bioethics think tank in Garrison, New York. But Murray, who in 2004 served on a panel that examined the NIH's conflict-of-interest policies, says the long-term impact may not be significant. The public, he says, may perceive it "as just one isolated, egregious case."

Meredith Wadman, Washington, DC 